
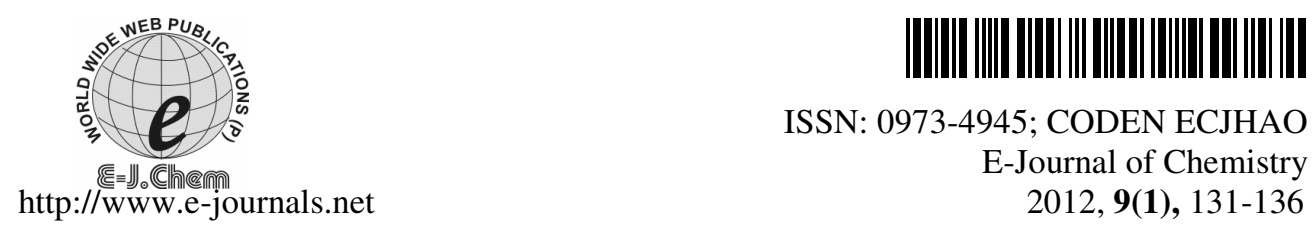

ISSN: 0973-4945; CODEN ECJHAO

E-Journal of Chemistry 2012, 9(1), 131-136

\title{
Reductive Cleavage of 1,2-Oxazines Promoted by Zinc and Ammonium Chloride; Mild One Pot Preparation of $\boldsymbol{\gamma}$-Hydroxy Ketones
}

\author{
P. SUNIL KUMAR ${ }^{*}$ and K. M. LOKANATHA RAI \\ *FMC (I) R\&D Centre, SID, \\ Indian Institute of Science Campus, Bangalore-12, India \\ Department of Studies in Chemistry, University of Mysore \\ Manasagangotri, Mysore, Karnataka- 570006, India \\ sunilkumarpookot@gmail.com
}

Received 4 June 2011; Accepted 12 August 2011

\begin{abstract}
A facile method for a mild single pot reductive cleavage of 1,2-oxazines to $\gamma$-hydroxy ketones was developed using zinc and aqueous ammonium chloride as the reagent in methanol. The reaction involves the reduction of $\mathrm{N}-\mathrm{O}$ bond of the oxazine and the hydrolysis of the resulting 1,4-iminoalcohol.
\end{abstract}

Keywords: Zinc, Ammonium chloride, Reductive cleavage, 1, 2-Oxazine, Cycloaddition

\section{Introduction}

[4+2] Cycloaddition of $\alpha$-nitrosoolefins with olefinic compounds are of synthetic interest since the product 5,6-dihydro- $4 H-1,2$-oxazines are versatile intermediates for the synthesis of bifunctional compounds ${ }^{1-3}$ as well as for the synthesis of naturally active compounds viz. alkaloids, amino sugars and unnatural amino acids ${ }^{4-10}$. The synthetic strategy generally employed here is the reductive cleavage of the oximino bond of the oxazines leading to the formation of various functional moieties like fused pyrrolidines ${ }^{11}$, pyridines ${ }^{12}$, nitrones ${ }^{13}$, 1,4 -aminoalcohols ${ }^{13}$ and $\gamma$-lactones ${ }^{14}$. The usual method for the reductive cleavage of oxazine involves the use of reducing agents like $\mathrm{H}_{2}$-Raney nickel ${ }^{15}, \mathrm{H}_{2}-\mathrm{Pd} / \mathrm{C}^{16}, \mathrm{LiAlH}_{4}{ }^{17-19}$, DIBAL- $\mathrm{H}^{20}$ and $\mathrm{Mo}(\mathrm{Co})_{6}{ }^{3}$. Literature reveals the relevance of transfer hydrogenation among different substrates ${ }^{21}$ and the use of zinc and ammonium chloride as transfer hydrogenation catalyst for the reduction of various compounds ${ }^{22}$. Here we report the conversion of 1,2-oxazines to $\gamma$-hydroxy ketones using zinc and ammonium chloride by cleavage of 1,2-oxazines followed by subsequent hydrolysis. 
[4+2] Cycloaddition of $\alpha$-nitrosoolefins derived from acetophenone derivatives with various alkenes afforded the starting 5,6-dihydro- $4 H$-1,2-oxazines. This procedure is based on Rai's method ${ }^{23}$. Typically, the reductions of the oxazines are carried out by heating a mixture of oxazines, zinc powder and ammonium chloride in methanol/water at $70{ }^{\circ} \mathrm{C}$. In general $\gamma$-hydroxy ketones are thus obtained in good yield.

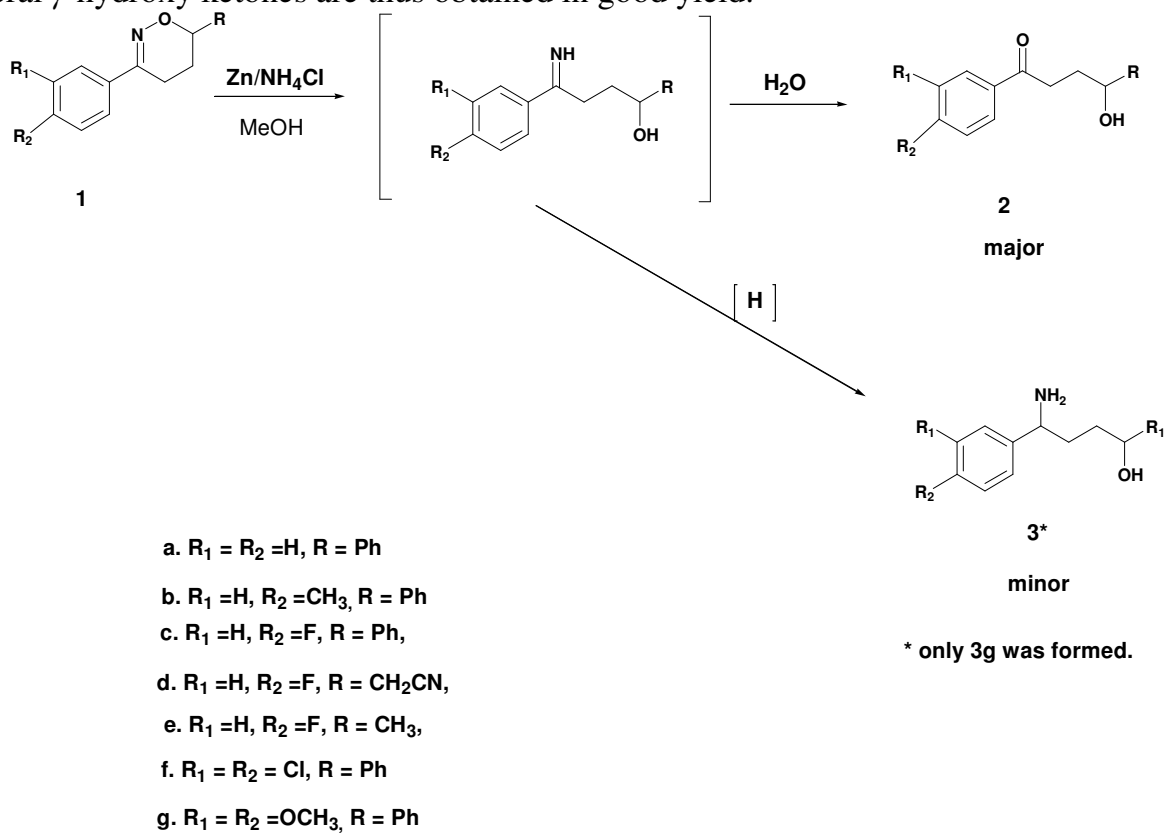

\section{Experimental}

Scheme 1

All chemicals used were lab grade chemicals without further purification. All reactions were monitored by TLC, which was performed on Merck Alumafoil $60 \mathrm{~A}^{\circ}$ TLC plates with an UV indicator. ${ }^{1} \mathrm{H}$ and ${ }^{13} \mathrm{C}$ NMR spectra were recorded using a $400 \mathrm{MHz}$ Bruker Avance Ultrashield NMR spectrometer (400.23 and $100.64 \mathrm{MHz}$, respectively) and referenced to $\mathrm{CDCl}_{3}$. Melting points are determined using a Campbell Electronics melting point apparatus. IR spectra were recorded using a JASCO FTIR-680 spectrophotometer. The elemental analysis of the compounds were carried out using Perkin Elmer 2400 series elemental analyzer and also by Orion ISE meter.

\section{General method for the reductive cleavage of oxazine}

\section{4-Hydroxy-4-phenyl-1-p-tolyl-butan-1-one (2b)}

In a typical procedure, to a stirred solution of 6-phenyl-3-p-tolyl-5,6-dihydro- $4 \mathrm{H}$ [1,2] oxazine (1b), $(0.9 \mathrm{~g}, 0.0036$ moles $)$ in methanol $(25 \mathrm{~mL})$ was added ammonium chloride $(1.91 \mathrm{~g}, 0.036$ moles $)$ in water $(7 \mathrm{~mL})$. Zinc powder $(0.70 \mathrm{~g}, 0.0108$ moles $)$ was then added to the reaction mixture and the solution heated to $70{ }^{\circ} \mathrm{C}$ for $3 \mathrm{~h}$. The reaction monitored by TLC after $3 \mathrm{~h}$ showed the absence of starting material. The solution was filtered to remove zinc/zinc oxide mixture. The filtrate was then extracted into ethyl acetate followed by washings with water. The organic layer was evaporated to get crude compound. The crude compound was purified by column chromagraphy using hexane/ethylacetate $(4: 1)$ to get $0.64 \mathrm{~g}$ of faint yellow oil. 
Yield: 70\%; IR (neat): 1675, $3411 \mathrm{~cm}^{-1} .{ }^{1} \mathrm{H}-\mathrm{NMR}\left(\mathrm{CDCl}_{3}\right): \delta 2.07-2.11(\mathrm{~m}, 2 \mathrm{H}), 2.22$ (br s, $1 \mathrm{H}, \mathrm{OH}$, replacement $\left.+\mathrm{D}_{2} \mathrm{O}\right), 2.32(\mathrm{~s}, 3 \mathrm{H}), 2.96-2.99(\mathrm{~m}, 2 \mathrm{H}), 4.69-4.72$ $(\mathrm{dd}, J=7.2 \mathrm{~Hz}, 1 \mathrm{H}), 7.1-7.3(\mathrm{~m}, 7 \mathrm{H}), 7.74-7.76(\mathrm{~m}, 2 \mathrm{H}) .{ }^{13} \mathrm{C}-\mathrm{NMR}\left(\mathrm{CDCl}_{3}\right): \delta 21.5,33,34$, 73.4, 125.7, 127.39, 128.18, 128.44, 134.36, 136.5, 143.8, 144.55, 200.2. Anal. Calcd. for $\mathrm{C}_{17} \mathrm{H}_{18} \mathrm{O}_{2}$ : C, 80.28; H, 7.13; O, 12.58. Found: C, 80.25; H, 7.17; O, 12.55 .

\section{Spectral Data}

\section{3, 6-Diphenyl-5,6-dihydro-4H-[1,2]oxazine (1a)}

Yield: $75 \%$, mp $154{ }^{\circ} \mathrm{C}\left(10 \%\right.$ ethanol in hexane), IR (KBr): $1563,1589 \mathrm{~cm}^{-1} .{ }^{1} \mathrm{H}-\mathrm{NMR}$ $\left(\mathrm{CDCl}_{3}\right): \delta 2.09-2.26(\mathrm{~m}, 2 \mathrm{H}), 2.65-2.69(\mathrm{~m}, 2 \mathrm{H}), 4.74-4.78(\mathrm{dd}, J=10.4 \mathrm{~Hz}, 1 \mathrm{H}), 7.25-7.36$ $(\mathrm{m}, 8 \mathrm{H}), 7.64-7.66(\mathrm{~m}, 2 \mathrm{H}) .{ }^{13} \mathrm{C}-\mathrm{NMR}\left(\mathrm{DMSO}-\mathrm{d}_{6}\right): \delta 21.9,25.4,76.45,125.2,126.6,128.0$, 128.4, 129.3, 135.7, 140.0, 154.5. Anal. Calcd. for $\mathrm{C}_{16} \mathrm{H}_{15} \mathrm{NO}$ : C, 80.98; H, 6.37; N, 5.90; O, 6.74. Found: C, 80.91; H, 6.32; N, 5.93; O, 6.77.

\section{6-Phenyl-3-(p-tolyl)-5,6-dihydro-4H-[1,2]oxazine (1b)}

Yield: $70 \%$, yellow solid, $\mathrm{mp} 146{ }^{\circ} \mathrm{C}\left(10 \%\right.$ ethanol in hexane), IR (KBr): $1561,1591 \mathrm{~cm}^{-1}$. ${ }^{1} \mathrm{H}-\mathrm{NMR}\left(\mathrm{CDCl}_{3}\right): \delta 2.14-2.23(\mathrm{~m}, 2 \mathrm{H}), 2.297(\mathrm{~s}, 3 \mathrm{H}), 2.65-2.68(\mathrm{~m}, 2 \mathrm{H}), 4.74-4.78$ $(\mathrm{dd}, J=10 \mathrm{~Hz}, 1 \mathrm{H}), 7.11-7.13(\mathrm{~d}, J=8.0 \mathrm{~Hz}, 2 \mathrm{H}), 7.25-7.37(\mathrm{~m}, 5 \mathrm{H}), 7.54-7.56(\mathrm{~m}, 2 \mathrm{H})$. ${ }^{13} \mathrm{C}-\mathrm{NMR}\left(\mathrm{CDCl}_{3}\right): \delta 21.3,22.3,26.1,76.9,125.27,126.47,128.13,128.51,129.15,133.01$, 139.54, 139.90, 154.35. Anal. Calcd. for $\mathrm{C}_{17} \mathrm{H}_{17} \mathrm{NO}$ : C, 81.24; H, 6.82; N, 5.57; O, 6.37. Found: C, 81.21; H, 6.84; N, 5.61; O, 6.36 .

\section{3-(4-Fluorophenyl)-6-phenyl-5,6-dihydro-4H-[1,2]oxazine (1c)}

Yield: $77 \%$, white crystals, mp: $160{ }^{\circ} \mathrm{C}\left(10 \%\right.$ ethanol in hexane), IR (KBr): $1563,1590 \mathrm{~cm}^{-1}$. ${ }^{1} \mathrm{H}-\mathrm{NMR}\left(\mathrm{CDCl}_{3}\right): \delta 2.08-2.18(\mathrm{~m}, 1 \mathrm{H}), 2.21-2.28(\mathrm{~m}, 1 \mathrm{H}), 2.64-2.68(\mathrm{~m}, 2 \mathrm{H}), 4.74-4.78$ $(\mathrm{dd}, J=10.4 \mathrm{~Hz}, 1 \mathrm{H}), 6.98-7.02(\mathrm{~m}, 2 \mathrm{H}), 7.26-7.37(\mathrm{~m}, 5 \mathrm{H}), 7.63-7.66(\mathrm{~m}, 2 \mathrm{H}) .{ }^{13} \mathrm{C}-\mathrm{NMR}$ $\left(\mathrm{CDCl}_{3}\right): \delta 22.3,25.9,26.1,77.0,115.32,115.54,126.46,127.18,127.26,128.24,128.56$, $128.60,131.94,131.98,139.63,153.43,162.36,164.84$. Anal. Calcd. for $\mathrm{C}_{16} \mathrm{H}_{14}$ FNO: C, 75.28; H, 5.53; F, 7.44; N, 5.49; O, 6.27. Found: C, 75.24; H, 5.56; F, 7.40; N, 5.45; O, 6.21.

\section{[3-(4-Fluorophenyl)-5,6-dihydro-4H-[1,2]oxazin-6-yl]-acetonitrile (1d)}

Yield: $47 \%$, mp: $110{ }^{\circ} \mathrm{C}\left(10 \%\right.$ ethanol in hexane), IR (KBr): 1557, 1598, $2235 \mathrm{~cm}^{-1} .{ }^{1} \mathrm{H}-\mathrm{NMR}$ $\left(\mathrm{CDCl}_{3}\right): \delta 1.90-1.92(\mathrm{~m}, 1 \mathrm{H}), 2.19-2.25(\mathrm{~m}, 1 \mathrm{H}), 2.62-2.72(\mathrm{~m}, 2 \mathrm{H}), 2.74-2.76(\mathrm{~m}, 1 \mathrm{H})$, $2.82(\mathrm{~m}, 1 \mathrm{H}), 2.89(\mathrm{~m}, 1 \mathrm{H}), 3.97-4.03(\mathrm{~m}, 1 \mathrm{H}), 6.99-7.04(\mathrm{~m}, 2 \mathrm{H}), 7.59-7.63(\mathrm{~m}, 2 \mathrm{H})$. ${ }^{13} \mathrm{C}-\mathrm{NMR}\left(\mathrm{CDCl}_{3}\right): \delta 21.4,22.8,23.6,70.04,115.5,115.8,115.9,128.3,129.0,154.2$, 162.6, 165.1. Anal. Calcd. for $\mathrm{C}_{12} \mathrm{H}_{11} \mathrm{FN}_{2} \mathrm{O}$ : C, 66.05; H, 5.08; F, 8.71; N, 12.84; O, 7.33. Found: C, 66.07; H, 5.04; F, 8.75; N, 12.88; O, 7.30.

\section{3-(4-Fluorophenyl)-6-methyl-5,6-dihydro-4H-[1,2]oxazine (1e)}

Yield: $61 \%$, mp $102{ }^{\circ} \mathrm{C}\left(10 \%\right.$ ethanol in hexane), IR (KBr): $1512,1607 \mathrm{~cm}^{-1} .{ }^{1} \mathrm{H}-\mathrm{NMR}$ $\left(\mathrm{CDCl}_{3}\right): \delta 1.31(\mathrm{~d}, J=6.4,3 \mathrm{H}), 1.71-1.72(\mathrm{~m}, 1 \mathrm{H}), 2.22-2.25(\mathrm{~m}, 1 \mathrm{H}), 2.79-2.82(\mathrm{~m}, 2 \mathrm{H})$, 3.64-3.67 (m, 1H), 6.90-7.04 (m, 2H), 7.48-7.57 (m, 2H). ${ }^{13} \mathrm{C}-\mathrm{NMR}\left(\mathrm{CDCl}_{3}\right): \delta 17.8,19.7$, 24.2, 70.7, 115.4, 115.6, 128.1, 128.7, 153.6, 162.3, 164.6. Anal. Calcd. for $\mathrm{C}_{1} \mathrm{H}_{12} \mathrm{FNO}$ : C, 68.38; H, 6.26; F, 9.83; N, 7.25; O, 8.28. Found: C, 68.33; H, 6.28; F, 9.85; N, 7.22; O, 8.29.

\section{3-(3,4-Dichlorophenyl)-6-phenyl-5,6-dihydro-4H-[1,2]oxazine (1f)}

Yield: $73 \%$, mp; $152{ }^{\circ} \mathrm{C}$ (10\% ethanol in hexane), IR (KBr): $1588,1595 \mathrm{~cm}^{-1} .{ }^{1} \mathrm{H}-\mathrm{NMR}$ $\left(\mathrm{CDCl}_{3}\right): \delta 2.072-2.157(\mathrm{~m}, 1 \mathrm{H}), 2.20-2.27(\mathrm{~m}, 1 \mathrm{H}), 2.58-2.67(\mathrm{~m}, 2 \mathrm{H}), 4.74-4.77(\mathrm{dd}, J=10.4$, 
$1 \mathrm{H}), 7.24-7.38(\mathrm{~m}, 6 \mathrm{H}), 7.47-7.50(\mathrm{dd}, J=2 \mathrm{~Hz}, 2 \mathrm{H}), 7.729-7.734(\mathrm{~d}, J=2 \mathrm{~Hz}, 1 \mathrm{H})$. ${ }^{13} \mathrm{C}-\mathrm{NMR}\left(\mathrm{CDCl}_{3}\right): \delta 22,25.56,77.28,124.4,126.4,127.2,128.3,128.6,130.4,132.77$, 133.5, 135.7, 139.2, 152.3. Anal. Calcd. for $\mathrm{C}_{16} \mathrm{H}_{13} \mathrm{Cl}_{2} \mathrm{NO}$ : C, 62.76; H, 4.28; $\mathrm{Cl}, 23.16 ; \mathrm{N}$, 4.57; O, 5.23. Found: C, 62.77; H, 4.30; Cl, 23.13; N, 4.55; O, 5.27.

\section{3-(3,4-Dimethoxyphenyl)-6-phenyl-5,6-dihydro-4H-[1,2]oxazine (1g)}

Yield: $77 \%, \mathrm{mp} ; 174{ }^{\circ} \mathrm{C}\left(10 \%\right.$ ethanol in hexane), IR (KBr): $1567,1603 \mathrm{~cm}^{-1} .{ }^{1} \mathrm{H}-\mathrm{NMR}$ $\left(\mathrm{CDCl}_{3}\right): \delta 2.22-2.24(\mathrm{~m}, 1 \mathrm{H}), 2.29-2.35(\mathrm{~m}, 1 \mathrm{H}), 2.74-2.78(\mathrm{~m}, 2 \mathrm{H}), 3.91(\mathrm{~s}, 3 \mathrm{H}) 3.92$ (s, 3H), 4.82-4.85 (dd, $J=10.4,1 \mathrm{H}), 6.85-6.87(\mathrm{~d}, J=8.4 \mathrm{~Hz}, 1 \mathrm{H}), 7.14-7.17$ (dd, $J=2.4 \mathrm{~Hz}$ and $2 \mathrm{~Hz}, 1 \mathrm{H}), 7.33-7.45(\mathrm{~m}, 5 \mathrm{H}), 7.488-7.493(\mathrm{~d}, J=2 \mathrm{~Hz}, 1 \mathrm{H}) .{ }^{13} \mathrm{C}-\mathrm{NMR}\left(\mathrm{CDCl}_{3}\right): \delta 2.1$, 26.1, 55.89, 55.91, 76.96, 108, 110.4, 118.2, 126.4, 128.2, 128.5, 128.6, 139.8, 148.9, 150.5, 153.8. Anal. Calcd.for $\mathrm{C}_{18} \mathrm{H}_{19} \mathrm{NO}_{3}: \mathrm{C}, 72.71 ; \mathrm{H}, 6.44 ; \mathrm{N}, 4.71 ; \mathrm{O}, 16.14$. Found: $\mathrm{C}, 72.73$; $\mathrm{H}, 6.41 ; \mathrm{N}, 4.69 ; \mathrm{O}, 16.17$.

\section{1-(4-Fluorophenyl)-4-hydroxy-4-phenyl-butan-1-one (2c)}

Yield: 76\%; oil; IR (neat): 1672, $3410 \mathrm{~cm}^{-1} .{ }^{1} \mathrm{H}-\mathrm{NMR}\left(\mathrm{CDCl}_{3}\right): \delta 2.10-2.15(\mathrm{~m}, 2 \mathrm{H}), 2.4$ (br s, $1 \mathrm{H}, \mathrm{OH}$, replacement $\left.+\mathrm{D}_{2} \mathrm{O}\right), 2.97-3.00(\mathrm{t}, J=7.2 \mathrm{~Hz}, 2 \mathrm{H}), 4.72-4.75(\mathrm{dd}, J=7.2 \mathrm{~Hz}, 1 \mathrm{H})$, 7.0-7.05 (m, 2H), 7.18-7.21 (m, 1H); 7.24-7.30 (m, 4H), 7.86-7.90(m, 2H). ${ }^{13} \mathrm{C}-\mathrm{NMR}$ $\left(\mathrm{CDCl}_{3}\right): \delta 33,34.6,73.5,115.5,115.73,125.7,127.6,128.4,130.7,133.3,134.36,136.5$, 164.5, 167, 198.8. Anal. Calcd. for $\mathrm{C}_{16} \mathrm{H}_{15} \mathrm{FO}_{2}$ : C, 74.40; H, 5.85; F, 7.36; O, 12.39. Found: C, 74.37; H, 5.81; F, 7.39; O, 12.36 .

\section{6-(4-Fluorophenyl)-3-hydroxy-6-oxo-hexanenitrile (2d)}

Yield: 63\%; oil; IR (neat): 1670, 3402, $2221 \mathrm{~cm}^{-1} .{ }^{1} \mathrm{H}-\mathrm{NMR}\left(\mathrm{CDCl}_{3}\right): \delta 1.82-1.84(\mathrm{~m}, 2 \mathrm{H})$, $2.4\left(\right.$ br s, $1 \mathrm{H}, \mathrm{OH}$, replacement $\left.+\mathrm{D}_{2} \mathrm{O}\right), 2.58-2.62(\mathrm{~m}, 2 \mathrm{H}), 3.0-3.02(\mathrm{~m}, 2 \mathrm{H}), 3.65-3.68(\mathrm{dd}$, $J=7.2 \mathrm{~Hz}, 1 \mathrm{H}), 6.9-7.02(\mathrm{~m}, 2 \mathrm{H}), 7.6-7.64(\mathrm{~m}, 2 \mathrm{H}) .{ }^{13} \mathrm{C}-\mathrm{NMR}\left(\mathrm{CDCl}_{3}\right): \delta 31.6,32.8,67.8$, 115.4, 115.73, 116.1, 130.7, 133.3, 167, 198.2. Anal. Calcd. for $\mathrm{C}_{12} \mathrm{H}_{12} \mathrm{FNO}_{2}$ : C, 65.15; $\mathrm{H}$, 5.47; F, 8.59; N, 6.33; O, 14.46. Found: C, 65.19; H, 5.44; F, 8.55; N, 6.37; O, 14.50.

\section{1-(3,4-Dichlorophenyl)-4-hydroxy-4-phenyl-butan-1-one (2f)}

Yield: 76\%; oil; IR (neat): 1688, $3430 \mathrm{~cm}^{-1} .{ }^{1} \mathrm{H}-\mathrm{NMR}\left(\mathrm{CDCl}_{3}\right): \delta 2.10$ (br s, $1 \mathrm{H}, \mathrm{OH}$, replacement $\left.+\mathrm{D}_{2} \mathrm{O}\right),(2.11-2.15(\mathrm{~m}, 2 \mathrm{H}), 2.97-3.03(\mathrm{~m}, 2 \mathrm{H}), 4.73-4.77(\mathrm{dd}, J=7.2 \mathrm{~Hz}, 1 \mathrm{H})$, 7.21-7.22 (m, 1H), 7.26-7.33 (m, 5H), 7.44-7.46 (d, $J=8.4 \mathrm{~Hz}, 1 \mathrm{H}), 7.67-7.74(\mathrm{~m}, 1 \mathrm{H})$, 7.84-7.94 (m, 1H). ${ }^{13} \mathrm{C}-\mathrm{NMR}\left(\mathrm{CDCl}_{3}\right): \delta 32.9,34.7,73.4,125.7,127.1,128.2,130.1,133.0$, 134.9,136.4, 138.41, 139.3, 144.1, 198.1. Anal. Calcd. for $\mathrm{C}_{16} \mathrm{H}_{14} \mathrm{Cl}_{2} \mathrm{O}_{2}$ : C, 62.15; $\mathrm{H}, 4.56$; $\mathrm{Cl}, 22.93$; O, 10.35. Found: C, 62.16; H, 4.58; Cl, 22.89; O, 10.33 .

\section{1-(3,4-Dimethoxyphenyl)-4-hydroxy-4-phenyl-butan-1-one (2g)}

Yield: 74\%; oil, IR (neat): 1677, $3418 \mathrm{~cm}^{-1} .{ }^{1} \mathrm{H}-\mathrm{NMR}\left(\mathrm{CDCl}_{3}\right): \delta 2.06-2.11(\mathrm{~m}, 2 \mathrm{H}), 2.4$ (br s, $1 \mathrm{H}, \mathrm{OH}$, replacement $\left.+\mathrm{D}_{2} \mathrm{O}\right), 2.96-2.99(\mathrm{~m}, 2 \mathrm{H}), 3.82(\mathrm{~s}, 1 \mathrm{H}), 3.84(\mathrm{~s}, 1 \mathrm{H}), 4.71-4.74$ $(\mathrm{dd}, J=7.2 \mathrm{~Hz}, 1 \mathrm{H}), 6.76-6.78(\mathrm{~m}, 1 \mathrm{H}), 7.18-7.19(\mathrm{~m}, 1 \mathrm{H}), 7.23-7.30(\mathrm{~m}, 4 \mathrm{H}), 7.42-7.74$ $(\mathrm{m}, 1 \mathrm{H}), 7.84-7.94(\mathrm{~m}, 1 \mathrm{H}) .{ }^{13} \mathrm{C}-\mathrm{NMR}\left(\mathrm{CDCl}_{3}\right): \delta 33.4,34.2,55.89,55.97,73.5,109.98$, 110.17, 115.33, 125.7, 127.15, 128.4, 129.44, 144.33, 149.26, 156.11, 199.3. Anal. Calcd. for $\mathrm{C}_{18} \mathrm{H}_{20} \mathrm{O}_{4}$ : C, 71.98; H, 6.71; O, 21.31. Found: C, 71.96; H, 6.73; O, 21.30.

4-Amino-4-(3,4-dimethoxy-phenyl)-1-phenyl-butan-1-ol (3g)

Yield: $2 \%$; solid; ${ }^{1} \mathrm{H}-\mathrm{NMR}\left(\mathrm{CDCl}_{3}\right): \delta 1.68-1.73(\mathrm{~m}, 2 \mathrm{H}), 1.78-1.81(\mathrm{~m}, 2 \mathrm{H}), 3.71(\mathrm{~s}, 1 \mathrm{H})$, $3.72(\mathrm{~s}, 1 \mathrm{H}), 3.92(\mathrm{t}, J=7.2 \mathrm{~Hz}, 1 \mathrm{H}), 4.62(\mathrm{dd}, J=7.2 \mathrm{~Hz}, 1 \mathrm{H}), 6.55-6.71(\mathrm{~m}, 3 \mathrm{H}), 7.15-7.17$ $(\mathrm{m}, 1 \mathrm{H}), 7.23-7.29(\mathrm{~m}, 4 \mathrm{H}) .{ }^{13} \mathrm{C}-\mathrm{NMR}\left(\mathrm{CDCl}_{3}\right): \delta 34.2,34.4,55.1,75.3,56.1,56.2,115.2$, 
125.3, 128.2, 128.3, 132.7, 139.4, 144.7. Anal. Calcd. for $\mathrm{C}_{18} \mathrm{H}_{23} \mathrm{NO}_{3}$ : C, 71.73; H, 7.69; N,4.65; O, 15.93. Found: C, 71.75; H, 7.71; N, 4.61; O, 15.90.

\section{Results and Discussion}

The oxazines with various functional groups were prepared by the $[4+2]$ cycloaddition reaction of $\alpha$-nitrosoolefins with alkenes, a method followed by Rai et $a l^{23}$. For instance, the 6-chloromethyl-3-(4-fluorophenyl)-5,6-dihydro-4H-[1,2]-oxazine was prepared from 4-fluoroacetophenone oxime and using allyl chloride as the alkene which was then converted to 3-(4-fluorophenyl)-6iodomethyl-5,6-dihydro- $4 H$-[1,2]-oxazine using $\mathrm{KI} /$ acetone as nucleophilic reagent. The 6-iodomethyl derivative was then reduced to 3-(4-fluorophenyl)-6-methyl-5,6-dihydro-4H-[1,2]-oxazine using zinc. The [3-(4-fluorophenyl)-5,6-dihydro- $4 H$-[1,2]-oxazin-6-yl]-acetonitrile was prepared by the reaction of sodium cyanide with 6-iodomethyl-3-(4-fluorophenyl)-5,6-dihydro- $4 \mathrm{H}$ $[1,2]$-oxazine. The oxazines were recrystallized from $10 \%$ ethanol in hexane.

The oxazines were reduced using zinc and ammonium chloride in methanol and water to corresponding $\gamma$-hydroxy ketones (Scheme 1). The reductive cleavage was accomplished using three moles of zinc and ten moles of ammonium chloride in methanol/water. The reaction stalled with lesser amounts of zinc and ammonium chloride. The reaction easily happened with 6-phenyl derivatives. With 6-methyl and 6-cyano methyl derivatives the reaction was sluggish. In these cases the reaction proceeded to completion at elevated temperatures.

Different reagents were tried for the conversion. Use of hydrogen/boric acid has been reported $^{24}$. Our trials using hydrogen gas and boric acid lead to cleavage of $\mathrm{N}-\mathrm{O}$ bonds but also resulted in the removal of some functional groups (eg: aromatic chloro group). Also there are some reports of the use of zinc/acetic acid/water ${ }^{25,26}$. for the cleavage but trials using the same for our substrates also resulted in the reduction of aromatic chloro groups in the system. Our screening of milder reagent for the preparation of $\gamma$-hydroxy ketones from 1, 2-oxazines led to the choice of the zinc and ammonium chloride which can accomplish the hydrogenolysis in a single pot.

The reactions were initiated at lower temperatures $\left(50{ }^{\circ} \mathrm{C}\right.$ and $\left.60{ }^{\circ} \mathrm{C}\right)$ but took longer time for completion. This also resulted in more tar formation. The temperature of $70{ }^{\circ} \mathrm{C}$ was the optimum temperature for the conversion. All the compounds were purified by column chromatography using hexane/ ethyl acetate as eluent and characterized by ${ }^{1} \mathrm{H}$ and ${ }^{13} \mathrm{C}-\mathrm{NMR}$. The yields of $\gamma$-hydroxy ketones (after column purification) were in the range of $63-76 \%$. The yield of compounds $\mathbf{2 a}$ and $\mathbf{2 e}$ are $72 \%$ and $75 \%$ respectively. The hydroxyl group in the $\gamma$-hydroxy ketones were characterized by ${ }^{1} \mathrm{H}-\mathrm{NMR}$ (by deuterium exchange using $\mathrm{D}_{2} \mathrm{O}$ ) and using IR-spectra.

The reductive cleavage using zinc and ammonium chloride reported here supersedes the other methods of reduction of 1, 2-oxazines in that it can be carried out without hydrogen gas, metals like Pd and Raney nickel and avoids expensive regents like $\mathrm{LiAlH}_{4}$, DIBAL-H. The other major advantage is that this reagent being milder, reduction can tolerate different functional groups like chloro, cyano and methoxy. The keto group in the product remained unaffected after the reaction.

The initial step of the reaction is the cleavage of the oximino bond of the oxazine to the 1,4-iminoalcohol. The hydrolysis of the imino-alcohol results in $\gamma$-hydroxy ketones. When the reaction was performed with electron donating groups on the phenyl ring at the 3 -position of the oxazine some traces of 1,4-aminoalcohols were also formed. These were formed from the subsequent reduction of 1,4-iminoalcohols. This is illustrated by the hydro 
genolysis of 3-(3,4- dimethoxyphenyl)-6-phenyl-5,6-dihydro-4H-[1,2]oxazine (1g) leading to the formation of minor amounts of 4-amino-4-(3,4-dimethoxy-phenyl)-1-phenyl-butan-1-ol (3g). 1,4-aminoalcohol (3g) formed were removed by column chromatography. 1,4-Aminoalcohols were not formed for other substrates probably due to the ease of hydrolysis of the intermediate 1,4- iminoalcohol with these substrates compared to the competitive hydrogenation reaction.

\section{Conclusion}

In conclusion, using zinc and ammonium chloride in methanol/water, an economical and convenient method of cleavage of oxazines to $\gamma$-hydroxy ketones is established. The mild one pot procedure tolerates various functional groups.

\section{Acknowledgment}

The authors thank FMC for providing the opportunity and support to do this work.

\section{References}

1. Gilchrist T L and Roberts T G, J Chem Soc Perkin Trans., 1983, 1, 1283.

2. Brandman H A and Conley R T, J Org Chem., 1973, 36, 2236.

3. Zimmer R and Reissig H U, J Org Chem., 1992, 57, 339.

4. Angermann J, Homann K, Reissig H U and Zimmer R, Synlett., 1995, 1014-1016.

5. Gallos J K, Sarli V C, Stathakis C I, Koftis T V, Nachmia V R and CoutouliArgyropoulou E, Tetrahedron, 2002, 58, 9351.

6. Gallos J K, Sarli V C, Varvogli A C, Papadoyanni C Z, Papaspyrou S D and ArgyroPoulos N G, Tetrahedron Lett., 2003, 44, 3905.

7. Gallos J K, Sarli V C, Massen Z S, Varvogli A C, Papadoyanni C Z, Papaspyrou S D and Argyropoulos N G, Tetrahedron, 2005, 61, 565.

8. Best W M, MacDonald J M, Skelton B W, Stick R V, Tilbrook D M G and White A H, Can J Chem., 2002, 80, 857-865.

9. Humphrey A J, Parsons S F, Smith M E B and Turner N J, Tetrahedron Lett., 2000, 41, 4481-4485.

10. Joubert M, Defoin A, Tarnus C and Streith, Synlett., 2000, 9, 1366.

11. Zimmer R, Collas M, Czerwonka R, Hain U and Reissig H U, Synthesis., 2008, 2, 237.

12. Faragher R and Gilchrist T L, J Chem Soc Perkin Trans 1, 1979, 258.

13. Hipelli C and Reissig H U, Liebigs Ann Chem., 1990, 5, 475-481.

14. Gilchrist T L, Lingham D A and Roberts T G, J Chem Soc Chem Commun., 1979, 1089-1090.

15. Reinhold Zimmer, Markus Collas, Michael Roth and Hans-Ulrich Reibig, Liebigs Ann Chem., 1992, 7, 709.

16. Reinhold Zimmer, Matthias Hoffmann and Hans-Ulrich ReiBig, Chemische Berichte, 1992, 125(10), 2243-2248.

17. Faragher R and Gilchrist T L J Chem Soc Perkin Trans 1, 1979, 249.

18. Hippeli C and ReiBig H U, Synthes., 1987, 1, 77.

19. Hans-Ulrich Reißig and Claudia Hippeli, Chemische Berichte, 1991, 124, 115-127.

20. Hipelli C and Reissig H U, Liebigs Ann Chem., 1990, 5, 475-481.

21. Gottfried Brieger and Terry Nestrick J, Chem Rev., 1974, 74(5), 567-580.

22. Abiraj K and Channe Gowda D, J Chem Res (S), 2003, 332.

23. Manjula M K, Rai K M L, Gaonkar S L, Raveesha K A and Satish S, Eur J Med Chem., 2009, 44(1), 280-488.

24. Ihl-Young Choi Lee, Jae Hyun Lee and Hyo Won Lee, Bull Korean Chem Soc., 2002, 23(4), 537.

25. Alexandros Makriyannis and Stephen Fesik, JACS, 1982, 104(23), 6642-6463.

26. Dwayne A Dias and Michael A Kerr, Organic Lett., 2009, 11(16), 3694-3697. 


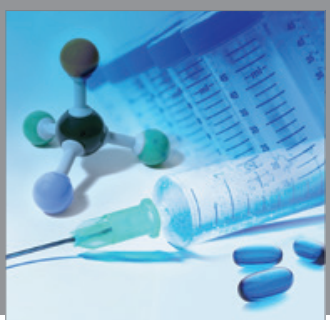

International Journal of

Medicinal Chemistry

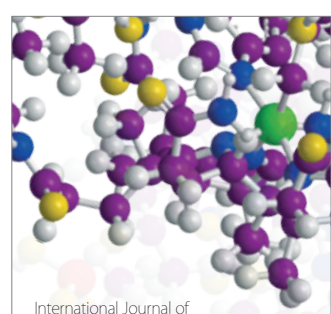

Carbohydrate Chemistry

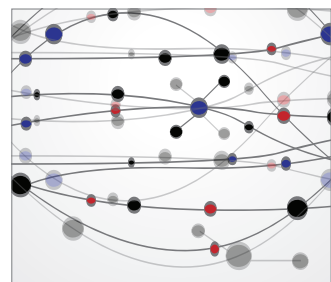

The Scientific World Journal
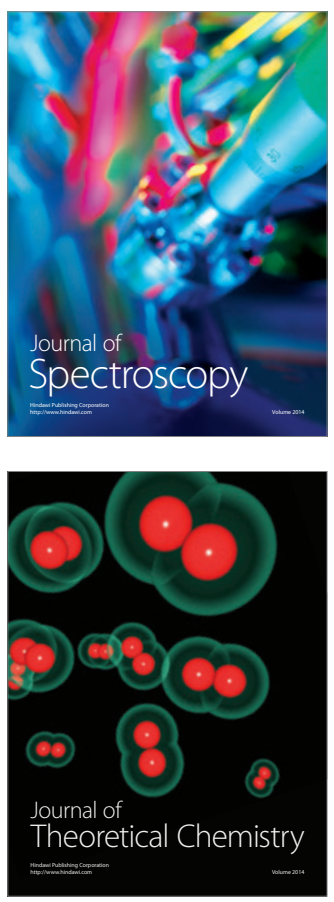
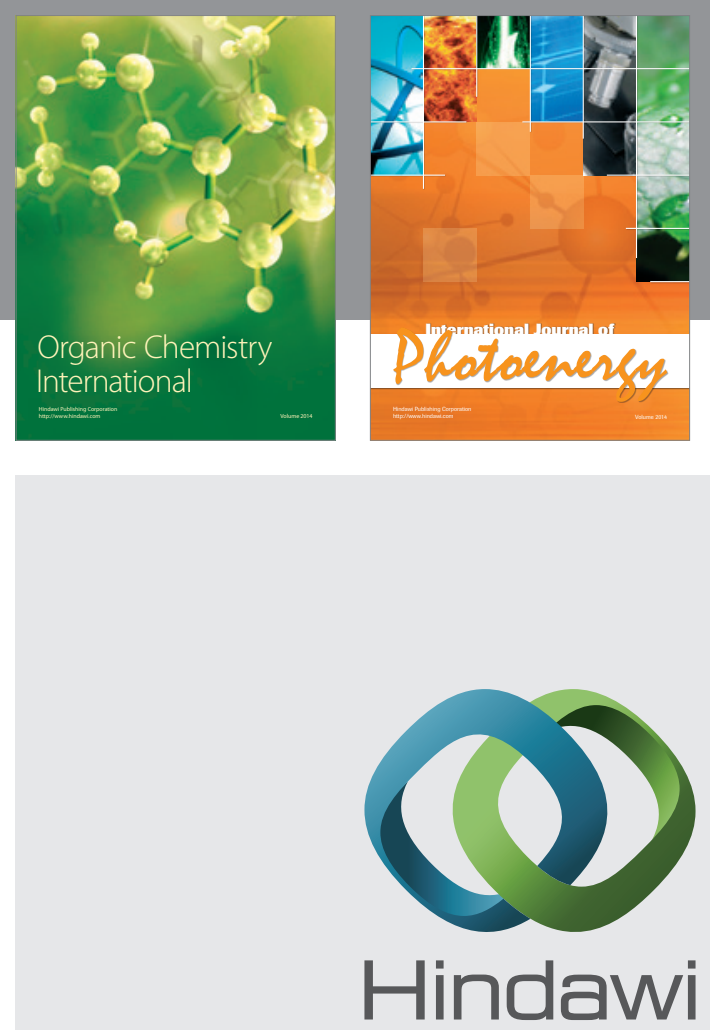

Submit your manuscripts at

http://www.hindawi.com
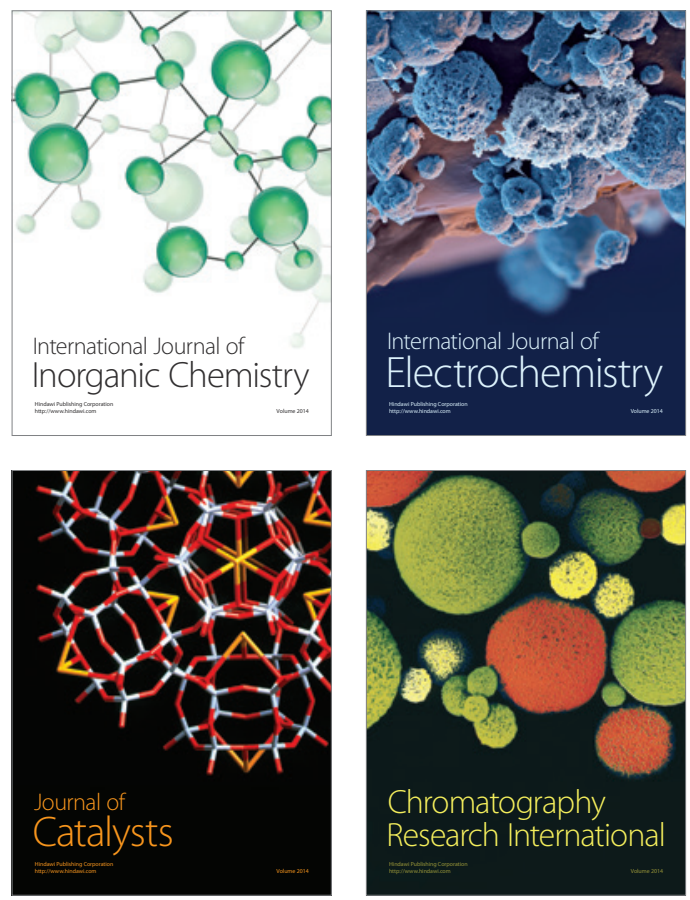
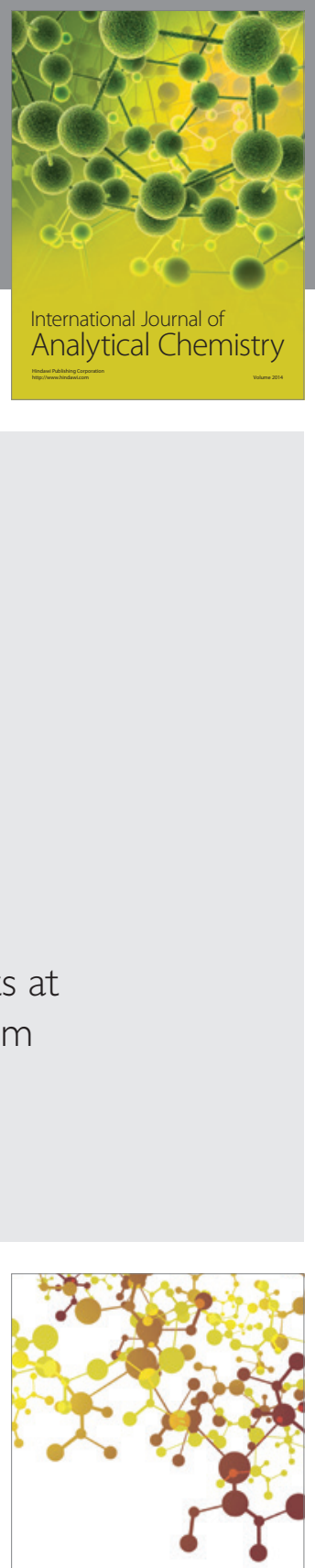

Journal of

Applied Chemistry
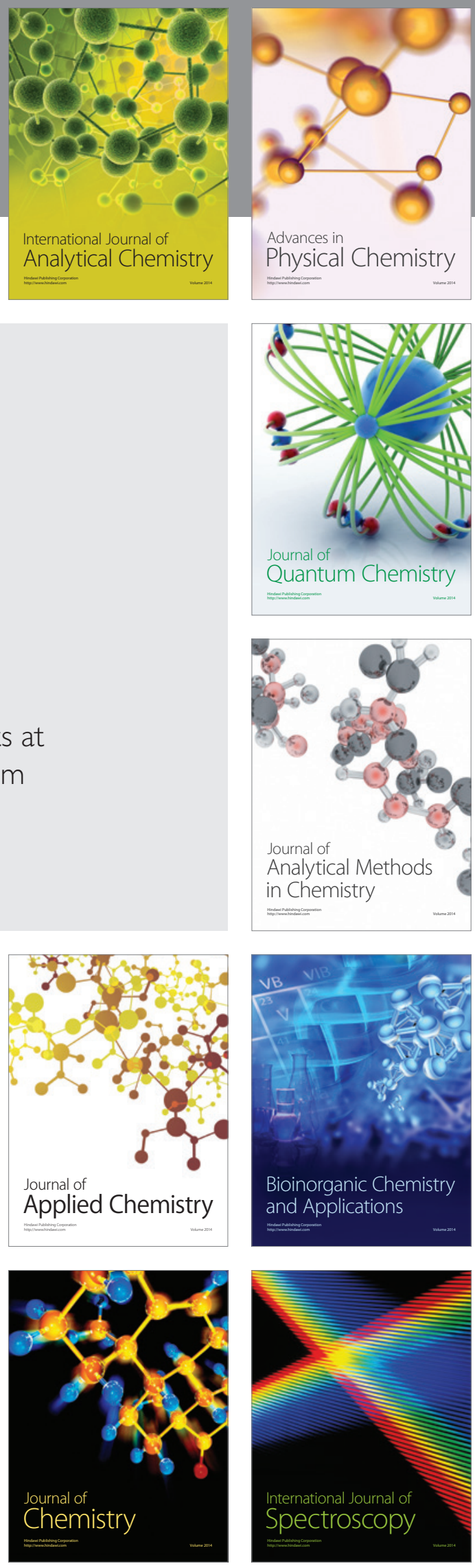